\title{
P-37 HABITAT OF MUD VOLCANOES AND PETROLEUM SEEPAGE IN AZERBAIJAN
}

Mud volcano is unique geological phenomenon localized within the boundaries of mobil belts. It is very important information source on age, composition of rocks not drilled in yet, as well as on fluids saturating them. In spite of a long history of study of this interesting phenomenon, there are a lot of debatable problems of mud volcanism. They are stratigraphic location of the "roots" of volcanoes, their relation with folded complex of different age, deep faults, diapir folds, seismic activity: formation and eruption mechanism; the place and role of mud volcanism in the system of geotectonical, gashydro- and thermodynamical processes, forming, redistribution and destroying oil and gas pools, features of mineral and ore forming.

Azerbaijan is considered classical region of mud volcanoes development, because maximal quantity of those concentrated here, the majority of which are connected with petroleum seepage. As it is known the main oil resources in Azerbaijan are concentrated in Lower Pliocene deposits (Productive Series), concerning the oil genesis the majority of researches have opinion up to now that this oil migrated from underlying deposits. Because our investigation devoted problems of mud volcanoes habitat and petroleum seepages in Azerbaijan. The study involved field geological reconnaissance mapping and geological inrpretation of satellite imagery.

Standartization of the regions of mud volcanism has the following positive characteristics, considerable facilitating the interpretation:

-practically all the mud volcanoes are topographically and structure-geomorphologically significant formations and digitally identified in the Landscape of any geotectonic region by specific morphoscupture and plastic of the shape;

-by photocolour and picture of anomalies it was substantiated the possibility of investigation of mud volcano pulsation and comparative dating by the habitats of spreading of mud breccia on condition of its incomplete covering by each next eruption;

-by the complex of direct interpretation indications for the geologically exposed territories, it was determined lineamental network and was carried out the comparsion with the fault tectonics of region for the setting degree of conformity;

-the region of any mud volcano is very complex built area of cumulative genesis and is represented by itself the composition of crossing tectonic breaks of different rank,complicated by near break plicative dislocation in the formation of which not the last role plays nonstationary viscid plastic stream of the Maykopian (Oligocene- lower Miocene) clayey thickness;

-photoanomaly of mud breccia of periodically stired up to activity mud volcanoes have the characteristic picture and colour for each effusion and is used for the area tracing of intensity of mud volcano activity in geologic history and for the determination of sequence phases of activization.

Landscape - indicative standartization of lineaments had been carried out on a territory of Azerbaijan and was under control by in-detail topographic maps of scale 1:25 000 and it had been permitted to mark out linear, bow-shaped and ring morphoelements, the reality of which 


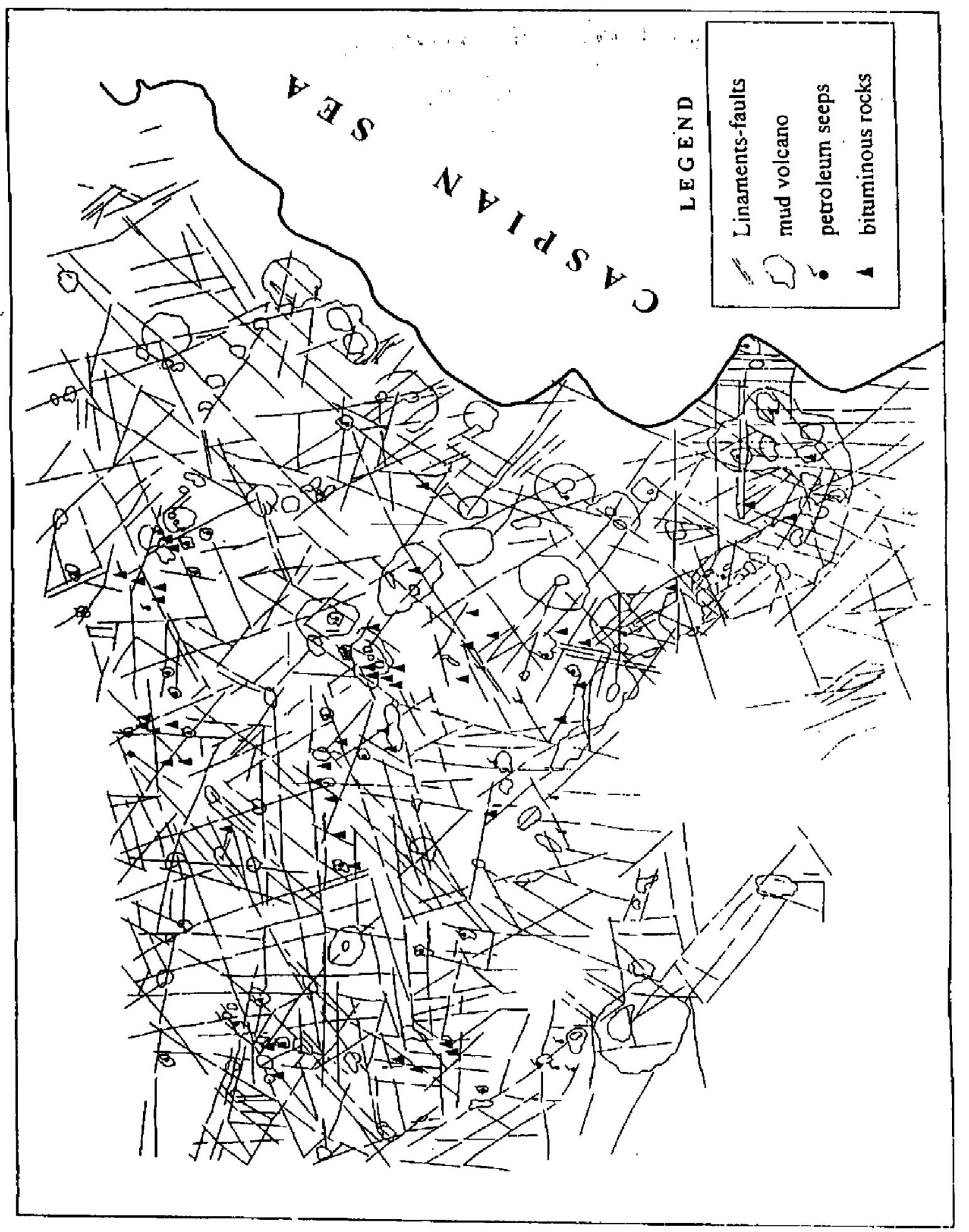

是

had been substantiated by the aggregate results of surface-geologic, structure-geologic and abyssal geophysic investigations (fig.1).

The total lineamental interpretation had shown the presence several classes of such units by it's manifestation on satellite images.

The seeming chaotic state in orientation and length of lineaments, and also its profusion had camouflaged its confining to that or another unit. 


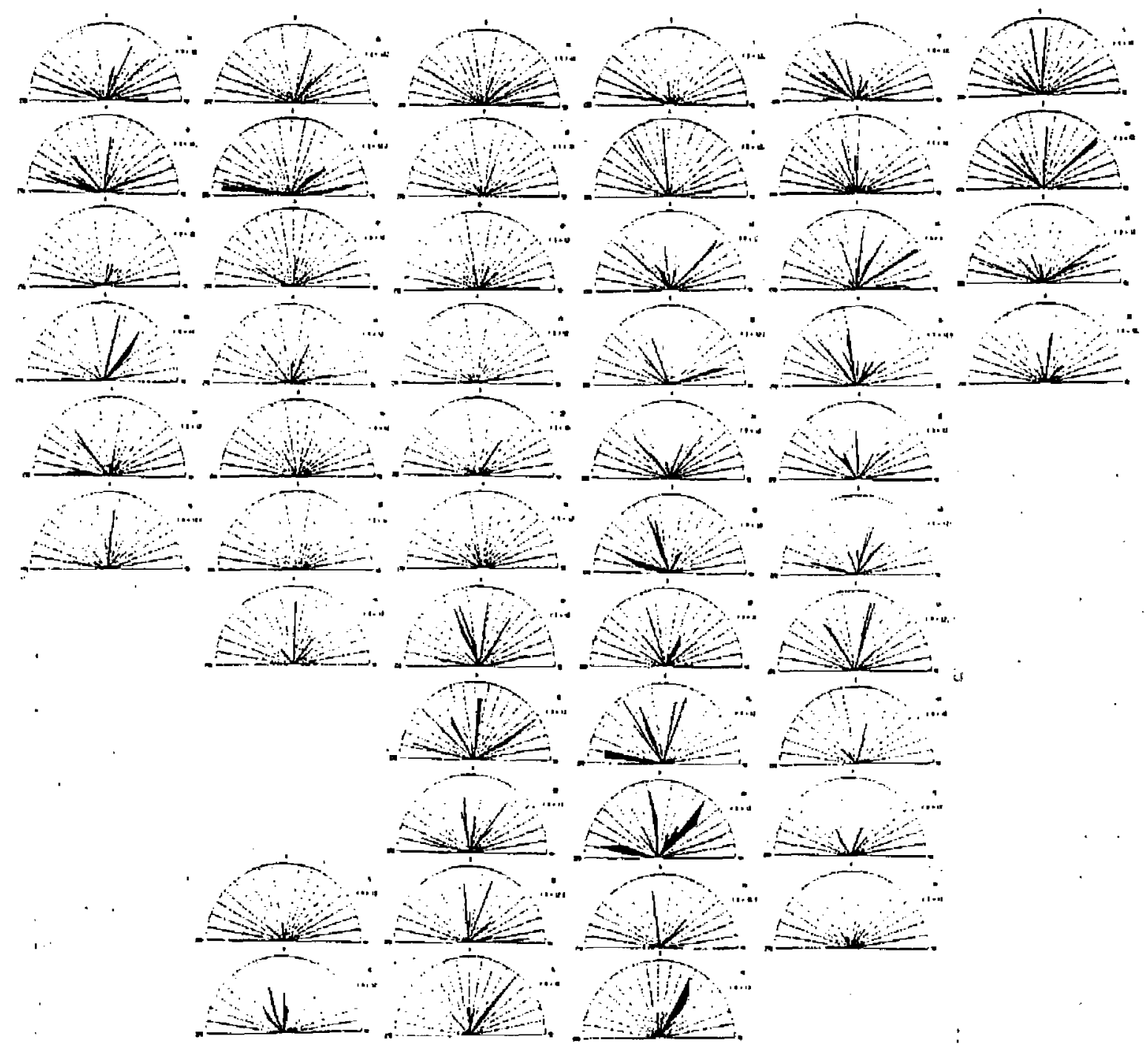

Fig.2. Rose-diagrams of the Azerbaijan mud volcanoes distribution areas

Table.1.Information about oil-bearingness of some structures, affected by mud volcanoes

\begin{tabular}{|c|c|c|c|c|}
\hline structure name & $\begin{array}{lr}\text { Availability } & \text { of } \\
\text { intensive } & \text { oil } \\
\text { seepages } & \end{array}$ & $\begin{array}{l}\text { Availabilit } \\
y \text { of oil } \\
\text { pools }\end{array}$ & $\begin{array}{l}\text { Thickness of } \\
\text { sediments covering the } \\
\text { Productive Series, in } \mathrm{m}\end{array}$ & $\begin{array}{l}\text { Mud volcano position } \\
\text { on structure }\end{array}$ \\
\hline Kalamadyn & $\ldots$ & + & 1700 & the north-west part of structure \\
\hline Kalamadyn & + & -.- & 0 & the south-east part of structure \\
\hline B. Kharami & + & --- & 0 & \\
\hline M.Kharami & ... & -.- & 0 & \\
\hline Kurovdag & $\ldots$ & + & $2000-2600$ & \\
\hline Babazanan & + & -- & 0 & \\
\hline Durovdag & --- & --- & 1600 & \\
\hline Khilli & -- & + & $900-1200$ & \\
\hline Nefichala & ... & t & $600-800$ & \\
\hline Kursangi & ... & + & 3000 & \\
\hline Mishovdag & $\ldots$ & + & 1500 & the west part of structure \\
\hline Mishovdag & + & --- & 0 & the central part of structure \\
\hline Kirkishlag & + & ... & 0 & \\
\hline Kalmas & -- & + & 1600 & \\
\hline Khidirli & $-\cdots$ & -.- & 500 & \\
\hline Bandovan & ... & $\ldots$ & $500-1200$ & \\
\hline Ayrantekan & + & -.- & 0 & . \\
\hline Shorbulag & + & --- & 0 & \\
\hline Dașhgil & -.- & t. & 0 & . \\
\hline
\end{tabular}


There were realized and presented graphically quantitative estimation in the shape of rose diagrams of asimuths of spreading and length of lineaments for the differentation of lineament network (fig.2).

On diagrams, confined to mud volcanoes, it is marked out maximum density of lineaments of distinct spreading, but not accordingly to length, that permited us to have a define oppinion - mud volcanoes are confined to tectonic knots of crossing of lineaments of different systems and are not depended from length of separate disjunctions, how imposing they are, i.e. mud volcanoes are structure-satellites of mentioned crossing of penertrating faults of different structural-tectonic storeys, indication of which was given accordingly ranked lineamental field, reflected the dynamics of transformation of tectonic strains in the region;

-increasing of density of lineaments in knots and systematic dimensions of mud volcanoes are situated in direct conformity, that confirmed the hypothesis of predominant role of fault - blocking constituent in formation of these morphostructures of cumulative genesis.

For the determination of role of lineamental tectonics in formation of mud volcano itself, there was carried out the estimation of density adopted extent of the lineaments by rose- diagrams with the center ingenuously upon mud volcanoes. By the results of these investigations it was determined the alternate slip of subordinated system of lineaments, coming together with the basic one at an angle of $30^{\circ}$.

It was determined, that lineamental tectonics is starting up system of faults, forming mud volcano itself, so as the dominant system of lineaments, azimuths extents of which are changing from 90 to $120^{\circ}$ provides the formation to not more than clayey diapir, and marked out system $\left(30^{\circ}\right)$ might be presented irrelative of system of basic lineaments. Autonomy of this system according to the extent should out on its subordinate character. Its role in the dynamics of mud volcanism comes to the slackening of physicalgeological state upon local formations and providing of break of visco plastic mass of clayey deposits.

Geological factors driving both mud volcanism and petroleum seepage in Azerbaijan coeval compressional tectonic stress, rapid the Paleogene-Quarternary sedimentation (more than $6 \mathrm{~km}$ of upperlayer sediment), and resulting abnormal pore pressures in both reservoir and non-reservoir rocks. Under these conditions, petroleum accumulation and preservation in the subsurface is perhaps remarkable.

Analysis of field survey and results of drilling on structures affected by mud volcanoes permitted to reveal the interesting regularity, which be able to serve as an important criterion of estimation of oilbearingness of these structures.

It is determined, that the structures, where the mud volcanism activity is accompained by intensive oil seepages on surface, as a rule, are not commercial oil-bearingness (table 1.).

Hence is made a conclusion, that absence of commercial oil pools in Productive Series (Lower Pliocene) deposits on structures with intensive oil seepages on mud volcanoes is stipulated by their desrtiction in connection with not enough thickness or full absence of deposits as well as Upper PlioceneQuarternary, so as Productive Series itself, recovering the assumed deposit. It is not contradicted to this conclusion, that case, when Productive Series deposits are revealing on surface (with absence of oil seepages).

Proceeding from above mentioned, there could be done a number of conclusion, which have important mearing for investigation works on structures, affected by mud volcanoes:

-among the structures, affected by mud volcano, the most interesting in consideration for revealing of commercial oil pools are such of them, on which the intensive oil seepages are absent;

if in different parts of one and the same structure are developed the several mud volcanoes, wells for investigation might be layed near such mud volcano, on which the intensive oil seepages are absent. 